\title{
Muscle Dysmorphia: Predictive and protective factors in adolescents
}

\section{Dismorfia muscular: factores predictivos y protectores en adolescentes}

\section{Dismorfia Muscular: Fatores preditivos e protetores em adolescentes}

\author{
Orrit, G. ${ }^{1}$, Pablos, A. ${ }^{2}$, Guzmán, F.J. ${ }^{3}$. \\ ${ }^{1}$ Doctoral School, Universidad Católica de Valencia San Vicente Mártir; ${ }^{2}$ Faculty of Physical Activity and \\ Sport Sciences, Universidad Católica de Valencia San Vicente Mártir; ${ }^{3}$ Faculty of Physical Education \\ and Sports, Universitat de València
}

\begin{abstract}
The Muscle Dysmorphia (MD) is a subcategory of body dysmorphic disorder in which subjects develop a pathological concern for their musculature. The population at risk that suffers from, or can develop MD, prevails in terms of age of appearance in subjects between 16 to 35 years; and it is more frequent in men. This study aimed to determine which variables of the personality, gender identity and passion (harmonious or obsessive) allow to predict MD in adolescents through the Adonis Complex (AC) Scale. A cross-sectional study was conducted on 506 subjects between 16 and 21 years $(\mathrm{M}=18.20 ; \mathrm{SD}=1.72)$. The higher correlation was between $\mathrm{AC}$ and Emotional Control in men, and impulse control in women. Then a binary logistic regression analysis was performed and model yielded $\mathrm{R} 2=.176(\mathrm{X} 2=47.95(16)<.001)$ and classified correctly in $88.5 \%$ of cases. Results of the analysis showed that harmonious passion $(\beta=-.028, \mathrm{p}=.046)$ and emotional control $(\beta=-.616, \mathrm{p}=.002)$ are protective variables while obsessive passion $(\beta=.065, \mathrm{p}=.013)$ and scrupulosity $(\beta=.344, \mathrm{p}=.046)$ were risk factors. The results show the importance of performing interventions aimed at the prevention of DM, starting from the relevance of working emotional control and harmonious passion in this stage of life and training.
\end{abstract}

Keywords: Vigorexia; Adonis Complex; Body Dimorphic Disorder.

\section{RESUMEN}

La Dismorfia Muscular (DM) es una subcategoría del trastorno dismórfico corporal en el que los sujetos desarrollan una preocupación patológica por su musculatura. La población en riesgo que sufre o puede desarrollar DM prevalece en términos de edad de aparición en sujetos de entre 16 y 35 años; Y es más frecuente en los hombres. Este estudio tuvo como objetivo determinar qué variables de la personalidad, la identidad de género y la pasión (armoniosa u obsesiva) permiten predecir la DM en adolescentes a través de la Escala del Complejo de Adonis (CA). Se realizó un estudio transversal en 506 sujetos entre 16 y 21 años $(\mathrm{M}=18.20 ; \mathrm{SD}=1.72)$. La mayor correlación fue entre CA y Control emocional en hombres y control de impulsos en mujeres. Luego se realizó un análisis de regresión logística binaria y el modelo produjo $\mathrm{R} 2=.176(\mathrm{X} 2=47.95(16)<.001)$ y se clasificó correctamente en el $88.5 \%$ de los casos. Los resultados del análisis mostraron que la pasión armoniosa $(\beta=-.028$, $\mathrm{p}=.046)$ y el control emocional $(\beta=-.616, \mathrm{p}=.002)$ son variables protectoras mientras que la pasión obsesiva $(\beta$ $=.065, \mathrm{p}=.013) \mathrm{y}$ escrupulosidad $(\beta=.344, \mathrm{p}=.046)$ fueron factores de riesgo. Los resultados muestran la importancia de realizar intervenciones dirigidas a la prevención de la DM, a partir de la relevancia del control emocional de trabajo y la pasión armoniosa en esta etapa de la vida y la formación.

Palabras clave: Vigorexia; Complejo de Adonis; Trastorno Dismorfico Corporal. 


\section{Muscle Dysmorphia in adolescents}

\section{RESUMO}

A dismorfia muscular (DM) é uma subcategoria do transtorno dismórfico corporal em que os indivíduos desenvolvem uma preocupação patológica pela sua musculatura. A população em risco que sofre ou pode desenvolver DM prevalece em termos de idade de aparecimento em indivíduos entre 16 a 35 anos; e é mais frequente nos homens. Este estudo teve como objetivo determinar quais variáveis da personalidade, identidade de gênero e paixão (harmoniosa ou obsessiva) permitem prever a DM em adolescentes por meio da Escala do Complexo de Adônis (CA). Um estudo transversal foi realizado em 506 sujeitos entre 16 e 21 anos (M = 18,20; SD $=1,72$ ). A maior correlação foi entre CA e Controle Emocional em homens e controle de impulso em mulheres. Em seguida, foi realizada uma análise de regressão logística binária e o modelo rendeu R2 =.176 (X2 = 47,95 (16) $<0,001)$ e classificado corretamente em $88,5 \%$ dos casos. Os resultados da análise mostraram que a paixão harmoniosa $(\beta=-.028, p=, 046)$ e controle emocional $(\beta=-.616, p=0,002)$ são variáveis de proteção, enquanto paixão obsessiva $(\beta=.065, \mathrm{p}=.013)$ e escrupulosidade $(\beta=, 344, \mathrm{p}=, 046)$ foram fatores de risco. Os resultados mostram a importância da realização de intervenções voltadas à prevenção do DM, a partir da relevância do controle emocional do trabalho e da paixão harmoniosa nesta etapa da vida e do treinamento.

Palavras chave: Vigorexia; Complexo Adonis; Transtorno Corporal Desmoronar.

\section{INTRODUCTION}

The latest edition of the Diagnostic and Statistical Manual of Mental Disorders (DSM-5) (American Psychiatric Association, 2013), integrates Muscle Dysmorphia (MD) into the obsessive-compulsive spectrum with various degrees of introspection. In addition to this, it conceptualizes it as a specific type of body dysmorphic disorder (MDD) (APA, 2013).

As early as 1993, Pope defined MD as a mental disorder caused by a distortion of body image (Pope, Katz, \& Hudson, 1993). The person who suffers from it perceives itself as small and weak when he or she is actually big and strong. This distortion causes a sickly obsession for developing muscle mass, which affects the psychological and social life of the individual, with even medical implications (Pope, et al., 2000).

MD is the concern of an individual for perceived defects or imperfections in physical appearance, which may be imperceptible or unimportant for other people, especially those related to body size and shape (González-Martí, Fernández, \& Contreras, 2012). This belief causes significant discomfort or social and occupational deterioration, since the idea that their body structure is too small or not very muscle is their main concern (APA, 2013).

Regarding prevalence, it is estimated that between 1 and $3 \%$ of the population suffers from MDD and at least $10 \%$ of people who undergo intensive training in the gym experience some symptoms of MD (Urlych, 2013; Melosik, 2010). The age of the population at risk that suffers or can develop this disorder is between 15 and 35 years old (Baile, 2005), although there are few studies conducted in the adolescent population. Bjornsson et al. (2013) show that the average age of onset is around 16-17 years. MD can be related with the hyper-muscle ideal of masculine beauty, which leads to the need to go to the gym and practice weight-lifting exercises, perform a very strict and limited diet or even ingest additional products (Walker, Anderson, \& Hildebrandt, 2009).

With regard to the factors that influence the appearance of this disorder, Baile (2005) identifies 3 types: the triggers, which would include those traumatic experiences with one's own body; the predisposing factors, among which include being between 18 and 35 years old, living in a body cult society, having obsessive-compulsive tendencies and having negative experiences with the body, and the maintenance factors, such as having a favorable environment, reinforcement and social recognition.

On the other hand, Grieve, (2007) states that the development of MD is due to a series of underlying factors, socio-environmental (representation of ideal body media and sports participation), emotional (negative affect), psychological (body dissatisfaction, idealization of the body, body distortion, 


\section{Orrit, G.; Pablos, A.; Guzmán, F.J.}

perfectionism, low self-esteem) and physiological factors (body mass). It also states that athletes who perform sports in which muscle development and appearance are important have a greater risk of developing $\mathrm{MD}$, and that is why studies carried out with bodybuilders or professional or elite athletes are common, as evidenced in the study conducted by Castro-López, Molero, Cachón-Zagalaz, \& SagalazSánchez, (2014) where it is reflected that there are different aspects in muscle building athletes linked to this pathology.

These models on the factors that contribute to the development of MD have been identified mostly in adults, with few studies in adolescents, in which the disorder tends to be underdiagnosed, and therefore there is little knowledge of the factors related to the disorder (Mitchell, Murray, Hoon, Hackett, \& Prvan, 2017). More information is needed to understand the prevalence of MD symptoms and related factors in adolescence.

On this basis, it was proposed to carry out a research with the objective of identifying predictive and protective factors of $\mathrm{MD}$, that allow the design of programs for MD prevention.

It was hypothesized that the social values of adolescents could be involved in the development of MD. The results of the study conducted by Cylwik and Starzomska (2013) indicate the relationship between the feeling of happiness and the critical environment on body image among men who train in a gym and show that the coexistence of these causes increases the risk of MD.

The predominant type of passion is one of the main aspects when explaining the integral well-being of a person (Vallerand \& Verner-Filion, 2013). The harmonious passion represents the intrinsic emotion composed for those activities that are freely chosen for the pleasure of performing them. This type of passion leaves the person spare time to perform other activities. The obsessive passion factor represents the extrinsic motivations (to please other people or to have a social status). It can become uncontrollable and leave the person without their own life, and can provoke feelings of guilt, anxiety and low self-esteem when the activity is not achieved completely (Orgambídez, Borrego, \& Gonçalves, 2014). In this study we hypothesized that harmonious passion would be a protective factor for MD whereas obsessive passion would be a risk factor.

On the other hand, the degree of concern about the physical aspect in the context of sports performance, where pressures may be related both to the body image and to the activities oriented to the musculature (Galli, Petrie, Reel, Greenlealf, \& Carter, 2015) would also be a risk factor for MD.

Regarding the emotional control value as a personality factor, it explains the tendency of some people to be more vulnerable to depression and anxiety problems when they encounter stressful situations and it has been related to a greater or lesser satisfaction in the different areas of life, as well as the ability to manage one's life in general, coinciding with the factors stated by Baile (2005) in the development of the disorder. People with high emotional stability have greater control over their emotions and are not easily affected by problems or setbacks in life. Scrupulosity is a manifestation of obsessive-compulsive disorder that represents a psychological disorder mainly characterized by the expression of a deep guilt and discomfort (Greenberg, Witztum, \& Pisante, 1987).

Likewise, cognitive behavioral models of MD describe certain personality traits as risk factors that predispose an individual to MD. Perfectionism is one of these personality traits. The model described by Wilhelm \& Steketee (2006) considers it a nonspecific vulnerability factor for the development of MD. Perfectionism leads these subjects to establish strict guidelines being extremely critical about themselves (Baile, 2005). It is considered that people with MD think and behave in a more perfectionist way than other people, therefore, it is contemplated that they perceive even almost imperceptible failures and intensify their focus on them, which leads them to have bad feelings and anguish when they cannot stand their imperfections (Wilhelm \& Steketee, 2006).

\section{MATERIALS AND METHODS}

A cross-sectional descriptive study was designed to examine the factors (personality, gender identity and passion) associated with Muscle Dysmorphia in adolescents. 


\section{Muscle Dysmorphia in adolescents}

\section{Participants}

The study included 506 adolescents of which 59\% were men (group1;n_1=296) with ages between 16 and 21 years $(\mathrm{M}=18.49, \mathrm{SD}=1.90)$ and $41 \%$ women (group2;n_2=210) between 16 and 21 years $(\mathrm{M}=17.90, \mathrm{SD}=1.86)$. They were selected by nonprobabilistic sampling. All of them met the inclusion criteria: being within the selected age ranges begin between 16 and 21 years old, having signed the consent to participate, reside and study within the province of Valencia and have completed all the administered questionnaires.

\section{Measures}

Demographics. In order to associate the sociodemographic or personal profile of the subjects with the variables established for the study, an "ad hoc" questionnaire was created in which basic data of age, height, weight and level of studies were collected.

Physical Exercise. To know the type and amount of physical exercise performed, an "ad hoc" Physical Exercise Questionnaire was administered in which data were collected on the type and frequency, intensity and duration of the exercise performed, as well as the place in which they practiced exercise, and if they did it competitively or not. Questions about diet and supplementation were also included.

Degree of concern for one's physical appearance. To know the degree of concern about physical appearance, the Spanish version of the Complex of Adonis scale was used (Baile, 2005). It consists of 13 items with 3 closed response options and whose score values are $A=0, B=1$ and $C=3$. Depending on the score obtained, we divided the participants into two groups. Those who scored less than nine were classified as subjects who did not have a pathological concern and were coded as group one. Those who scored nine or higher were classified as subjects at risk of Adonis Complex and were coded as group two.

The passion for sports. The passion for sports was measured with the adaptation to Spanish of The Passion Toward Work Scale (Orgambídez, Borrego, and Gonçalves, 2014). This instrument is composed of two factors: Harmonious Passion and Obsessive Passion. It consists of 14 items, with 7 items in each factor. Answers are Likert-type from 1 to 7 , where 1 means totally disagree and 7 totally agree.

Adolescent Positive Development. In order to know the importance that adolescents attach to the values involved in positive development, the Scale of Values for the Positive Development of Adolescents was used (Antolín, Oliva, Pertegal, \& López, 2011). This scale consists of 24 items grouped into eight subscales: social commitment, prosociability, justice and equality, honesty, integrity, responsibility, social recognition and hedonism. The answers are made using a Likert-type scale from 1 to 7 , where 1 means totally disagree and 7 totally agree.

Personality. To know the personality of the adolescents, the Spanish adaptation of the Big Five Questionnaire was used (Bermudez, 1995). For this study, 3 of the 5 dimensions (emotional stability, self-control and energy) were used, with a total of 70 items, since it was hypothesized that they could be related to the Adonis Complex. The dimension of Emotional Stability was used to know the level of emotion, irritability and impulse that a person demonstrates in their actions. With the dimension of Self Control, we wanted to know if the participants were persevering and orderly people, controlling their environment in that way. Finally, with the Energy dimension we wanted to know the level of activity and energy that each person transmits when performing a specific task. For the answers a Likerttype scale from 1 to 5 was used, where 1 means not agreeing and 5 strongly agree.

\section{Procedures}

Ethical approval for the study was granted by the ethics committee of the University of Valencia, and the research process met APA and BPS ethical standards.

The participants signed an informed consent, which indicated that the data provided would be anonymous and for investigation purposes. They then filled out a notebook consisting of a total of five questionnaires in the presence of a researcher.

\section{Statistical analysis}

In order to carry out the pertinent statistical analyses, SPSS program version 23.0 was used. To know the 


\section{Orrit, G.; Pablos, A.; Guzmán, F.J.}

degree of joint variation between the variables, that is, the linear association between variables, bivariate correlation analysis was used.

To analyze the predictive character of the variables, a binary logistic regression analysis was performed, given that the values of the Adonis Complex were 1 and 2. In this case, the variable can be assumed to be dichotomous and we understand that the participants who scored two are more vulnerable to suffer from bigorexia.

\section{RESULTS}

\section{Correlation analysis}

The relationships between the Adonis Complex, passion (Obsessive and Harmonious), and the personality of adolescents based on sex can be seen in Table 1 for men and Table 2 for women. After performing the bivariate correlation analysis (Pearson), the most relevant results are shown.

In men, the data obtained indicate that the Adonis Complex correlates in a positive way with Scrupulosity $\mathrm{r}(294)=.120, \quad \mathrm{p}<.05$ and Social Recognition $\mathrm{r}(294)=.129, \mathrm{p}<.05$; and in a negatively way with Emotional Control $\mathrm{r}(294)=.234, \mathrm{p}<.01$ and Impulse Control $\mathrm{r}(294)=-.122, \mathrm{p}<.05$.

As for women, the data obtained indicate that the Adonis Complex does not correlate positively with any of the variables; and in a negative way it correlates with Emotional Control r(208)=-.159, $\mathrm{p}<.05)$ and Impulse Control $\mathrm{r}(208)=-.163, \mathrm{p}<.05)$.

\section{Predictive analysis}

A binary logistic regression analysis was performed for the complete sample (men and women) (Table 3). The model yielded R2=.176 (X2=47.95 (16) <.001) and classified correctly $88.5 \%$ of cases. The regression equation was:

Adonis Complex $=-2.78-(.06 \mathrm{x}$ Integrity $)+(.02 \mathrm{x}$ Honesty $)+(.10 \mathrm{x}$ Responsibility $)+(.10 \mathrm{x}$ Social Commitment $)-(.04 \times$ Prosociability $)-(.11 \times$ Justice and Equality $)+(.03 \times$ Hedonism $)+(.00 \times$ Social Recognition $)-(.02 \times$ Harmonious Passion $)+(.06 \mathrm{x}$ Obsessive Passion $)+(.24 \times$ Dynamism $)-(.20 \mathrm{x}$
Domination $)$ - $(.17 \mathrm{x}$ Impulse Control $)-(.61 \mathrm{x}$ Emotional Control $)+(.34 \mathrm{x}$ Scrupulosity $)-(.27 \mathrm{x}$ Perseverance)

The predictive capacity of the variables it is shown in Table 3, where it is observed that the harmonious passion, $(\beta=-.028, \mathrm{p}=.046)$ and emotional control $(\beta=-.616, p=.002)$ were protective variables because they predicted the Adonis Complex significantly and negatively, while the obsessive passion $(\beta=.065$, $\mathrm{p}=.013)$ and scrupulosity $(\beta=.344, \mathrm{p}=.046)$ were risk factors, interacting positively with it.

On the other hand, it was observed a tendency that the value of justice and equality was protective $(\beta=-$ $.117, \mathrm{p}=.064)$, and a tendency that social commitment was a risk factor $(\beta=.104, p=.058)$. When applying the Hosmer and Lemeshow test, it indicated an adequate deviation adjustment $(\mathrm{X} 2=13.69(8) ; \mathrm{p}$ $=.090$ ).

Regarding men, the same tendency was observed. The model yielded $\mathrm{R} 2=.247 \quad(\mathrm{X} 2=39.28 \quad(16)=.001)$ and classified correctly $89.5 \%$ of cases. The regression equation was:

Adonis Complex $=-2.49-(.12 \mathrm{x}$ Integrity $)+(.05 \mathrm{x}$ Honesty $)+(.11 \times$ Responsibility $)+(.13 \times$ Social Commitment $)-(.11 \mathrm{x}$ Prosociability $)-(.10 \mathrm{x}$ Justice and Equality $)+(.02 \times$ Hedonism $)+(.10 \times$ Social Recognition $)-(.05 \times$ Harmonious Passion $)+(.04 \times$ Obsessive Passion $)+(.17 \mathrm{x}$ Dynamism $)+(.01 \mathrm{x}$ Domination $)$ - $(.06 \mathrm{x}$ Impulse Control $)-(.93 \mathrm{x}$ Emotional Control $)+(.55 \times$ Scrupulosity $)-(.27 \mathrm{x}$ Perseverance)

Further highlight the importance of emotional control value $(\beta=-.936, p=.001)$ as protective factor and scrupulosity value $(\beta=.551, \mathrm{p}=.034)$ as a risk factor. Add what was observed a tendency that social commitment was a risk factor $(\beta=.130, \mathrm{p}=.068)$. The Hosmer and Lemeshow test indicated an adequate deviation adjustment $(\mathrm{X} 2=4.65(8) ; \mathrm{p}=.079)$.

For women, the same tendency was observed, but the model was not significative. The model yielded $\mathrm{R} 2=.199 \quad(\mathrm{X} 2=23.28 \quad(16)=.11)$, and classified correctly $86.7 \%$ of cases. The regression equation was: 


\section{Muscle Dysmorphia in adolescents}

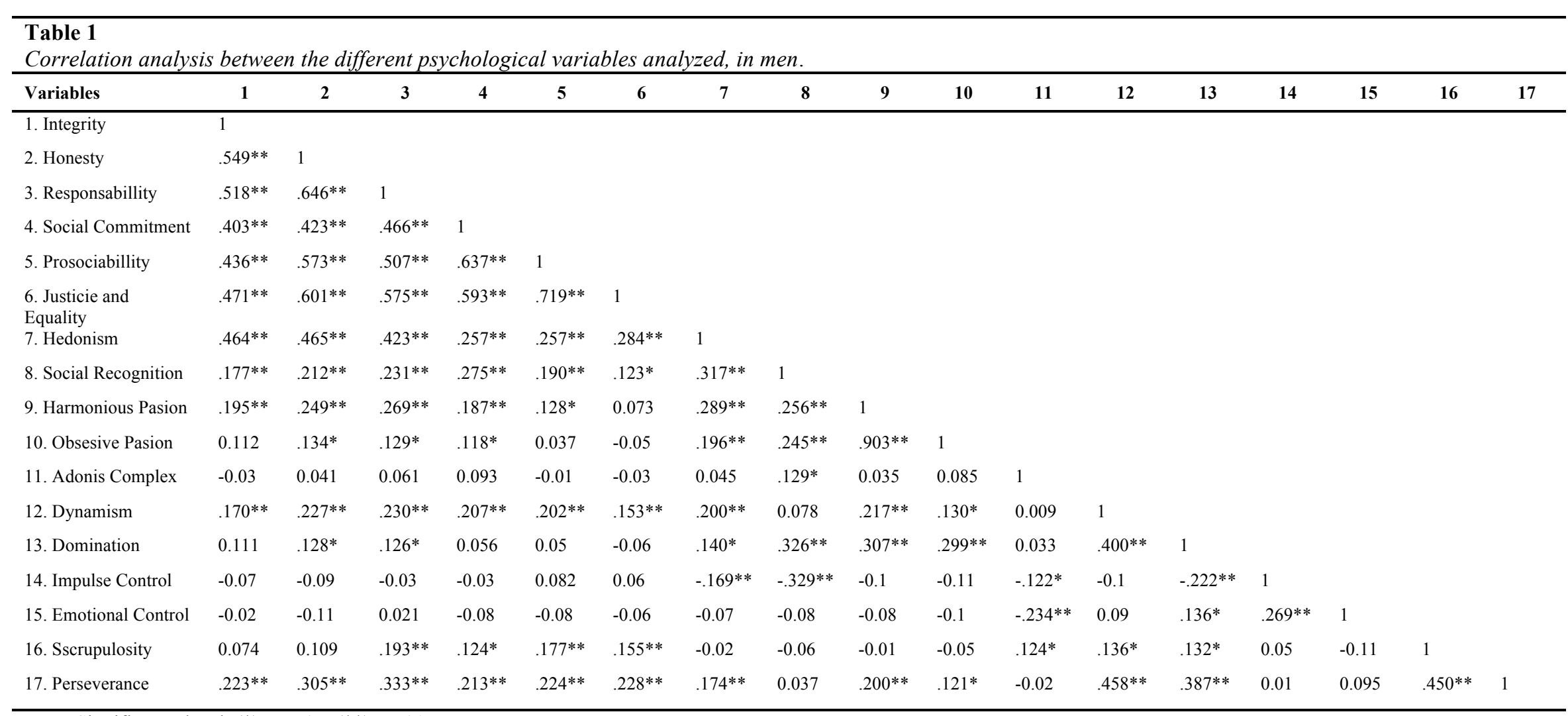

Note: Significance level: (*) $P<.05 ;(* *) \mathrm{P}<.01$ 


\section{Orrit, G.; Pablos, A.; Guzmán, F.J.}

Table 2

Correlation analysis between the different psychological variables analyzed, in women.

\begin{tabular}{|c|c|c|c|c|c|c|c|c|c|c|c|c|c|c|c|c|c|}
\hline Variables & 1 & 2 & 3 & 4 & 5 & 6 & 7 & 8 & 9 & 10 & 11 & 12 & 13 & 14 & 15 & 16 & 17 \\
\hline 1. Integrity & 1 & & & & & & & & & & & & & & & & \\
\hline 2. Honesty & $.491^{* *}$ & 1 & & & & & & & & & & & & & & & \\
\hline 3. Responsabillity & $.431 * *$ & $.582 * *$ & 1 & & & & & & & & & & & & & & \\
\hline 4. Social Commitment & $.358 * *$ & $.369^{* *}$ & $.316^{* *}$ & 1 & & & & & & & & & & & & & \\
\hline 5. Prosociabillity & $.475^{* *}$ & $.532 * *$ & $.419 * *$ & $.601 * *$ & 1 & & & & & & & & & & & & \\
\hline $\begin{array}{l}\text { 6. Justicie and } \\
\text { Equality }\end{array}$ & $.473 * *$ & $.559^{* *}$ & $.410^{* *}$ & $.464 * *$ & $.600 * *$ & 1 & & & & & & & & & & & \\
\hline 7. Hedonism & $.469^{* *}$ & $.369^{* *}$ & $.226 * *$ & $.354 * *$ & $.325^{* *}$ & $.238 * *$ & 1 & & & & & & & & & & \\
\hline 8. Social Recognition & 0.113 & $.182^{* *}$ & 0.093 & $.196^{* *}$ & $.226^{* *}$ & 0.1 & $.242 * *$ & 1 & & & & & & & & & \\
\hline 9. Harmonious Pasion & -0.005 & 0.066 & 0.087 & $.148^{*}$ & 0.08 & 0.021 & 0.129 & 0.078 & 1 & & & & & & & & \\
\hline 10. Obsesive Pasion & -0.056 & 0.02 & 0.022 & $.156^{*}$ & 0.08 & 0.007 & 0.122 & $.150^{*}$ & $.886 * *$ & 1 & & & & & & & \\
\hline 11. Adonis Complex & 0.032 & 0.054 & 0.071 & 0.058 & 0.056 & -0.009 & 0.085 & -0.056 & 0.046 & 0.102 & 1 & & & & & & \\
\hline 12. Dynamism & 0.124 & $.152^{*}$ & $.226^{* *}$ & $.227 * *$ & $.150^{*}$ & 0.109 & $.223^{* *}$ & 0.021 & $.341 * *$ & $.329 * *$ & 0.094 & 1 & & & & & \\
\hline 13. Domination & -0.042 & -0.059 & -0.064 & 0.028 & -0.06 & 0.013 & 0.039 & $.174 *$ & $.257 * *$ & $.291 * *$ & -0.075 & $.405^{* *}$ & 1 & & & & \\
\hline 14. Impulse Control & -0.069 & -0.085 & -0.1 & -0.048 & -0.075 & -0.036 & -0.13 & -0.066 & -0.057 & -0.108 & $-.163 *$ & $-.297 * *$ & $-.137 *$ & 1 & & & \\
\hline 15. Emotional Control & -0.111 & $-.215 * *$ & $-.171^{*}$ & -0.025 & $-.162 *$ & $-.197^{* *}$ & -0.054 & $-.163^{*}$ & 0.033 & 0.017 & $-.159^{*}$ & 0.082 & 0.056 & $.463^{* *}$ & 1 & & \\
\hline 16. Sscrupulosity & 0.095 & 0.125 & $.172 *$ & -0.003 & 0.127 & 0.094 & 0.049 & 0.037 & 0.123 & 0.11 & 0.061 & 0.118 & $.268^{* *}$ & -0.026 & $-.185 * *$ & 1 & \\
\hline 17. Perseverance & 0.048 & 0.106 & $.157^{*}$ & -0.001 & 0.06 & 0.135 & -0.011 & -0.123 & $.154 *$ & 0.112 & -0.039 & $.388^{* *}$ & $.415^{* *}$ & -0.045 & 0.051 & $.382 * *$ & 1 \\
\hline
\end{tabular}

Note: Significance level: $(*) P<.05 ;(* *) \mathrm{P}<.01$

Osociedad 2 Seroamericana de


Orrit, G.; Pablos, A.; Guzmán, F.J.

Table 3

Ability of the model variables to predict muscle dysmorphia in the complete sample, men and women.

\begin{tabular}{|c|c|c|c|c|c|c|c|}
\hline Variables & & $B$ & Standard Error & Wald & df & Sig. & $\operatorname{Exp}(B)$ \\
\hline & Total & -.069 & .054 & 1.621 & 1 & .203 & .933 \\
\hline \multirow[t]{3}{*}{ Integrity } & Men & -.120 & .078 & 2.345 & 1 & .126 & .887 \\
\hline & Women & -.016 & .086 & .033 & 1 & .855 & 984 \\
\hline & Total & .023 & .070 & .111 & 1 & .740 & 1.023 \\
\hline \multirow[t]{3}{*}{ Honesty } & Men & .057 & .097 & .344 & 1 & .557 & 1.059 \\
\hline & Women & .022 & .112 & .038 & 1 & .845 & 1.022 \\
\hline & Total & .103 & .068 & 2.288 & 1 & .130 & 1.108 \\
\hline \multirow[t]{3}{*}{ Responsibility } & Men & .119 & .092 & 1.661 & 1 & .197 & 1.126 \\
\hline & Women & .066 & .113 & .347 & 1 & .556 & 1.069 \\
\hline & Total & .104 & .055 & 3.604 & 1 & .058 & 1.109 \\
\hline \multirow[t]{3}{*}{ Social Commitment } & Men & .130 & .071 & 3.323 & 1 & .068 & 1.139 \\
\hline & Women & .034 & .094 & .129 & 1 & .720 & 1.034 \\
\hline & Total & -.046 & .061 & .559 & 1 & .455 & .955 \\
\hline \multirow[t]{3}{*}{ Prosociability } & Men & -.111 & .090 & 1.527 & 1 & .217 & .895 \\
\hline & Women & .005 & .092 & .003 & 1 & .958 & 1.005 \\
\hline & Total & -.117 & .063 & 3.434 & 1 & .064 & .890 \\
\hline \multirow[t]{3}{*}{ Justice and Equality } & Men & -.106 & .089 & 1.431 & 1 & .232 & .899 \\
\hline & Women & -.100 & .101 & .972 & 1 & .324 & .905 \\
\hline & Total & .037 & .048 & .581 & 1 & .446 & 1.038 \\
\hline \multirow[t]{3}{*}{ Hedonism } & Men & .023 & .072 & .103 & 1 & .748 & 1.023 \\
\hline & Women & .049 & .071 & .473 & 1 & .492 & 1.050 \\
\hline & Total & .003 & .040 & .006 & 1 & .939 & 1.003 \\
\hline \multirow[t]{3}{*}{ Social Recognition } & Men & .101 & .062 & 2.652 & 1 & .103 & 1.106 \\
\hline & Women & -.090 & .065 & 1.925 & 1 & .165 & .914 \\
\hline & Total & -.028 & .014 & 3.982 & 1 & .046 & .972 \\
\hline \multirow[t]{3}{*}{ Harmonious Passion } & Men & -.047 & .025 & 3.523 & 1 & .061 & .954 \\
\hline & Women & -.034 & .020 & 2.914 & 1 & .088 & 967 \\
\hline & Total & .065 & .026 & 6.228 & 1 & .013 & 1.067 \\
\hline \multirow[t]{3}{*}{ Obssesive Passion } & Men & .073 & .043 & 2.973 & 1 & .085 & 1.076 \\
\hline & Women & .085 & .038 & 5.130 & 1 & .024 & 1.089 \\
\hline & Total & .243 & .200 & 1.482 & 1 & .223 & 1.275 \\
\hline \multirow[t]{3}{*}{ Dynamism } & Men & .179 & .258 & .479 & 1 & .489 & 1.196 \\
\hline & Women & .483 & .343 & 1.979 & 1 & .159 & 1.621 \\
\hline & Total & -.201 & 196 & 1.051 & 1 & .305 & .818 \\
\hline \multirow{3}{*}{ Domination } & Men & .015 & .274 & .003 & 1 & .957 & 1.015 \\
\hline & Women & -.500 & .321 & 2.424 & 1 & .119 & 606 \\
\hline & Total & -.176 & 161 & 1.198 & 1 & .274 & .838 \\
\hline \multirow[t]{3}{*}{ Impulse Control } & Men & -.065 & .230 & .080 & 1 & .777 & 937 \\
\hline & Women & -.275 & .272 & 1.019 & 1 & .313 & .760 \\
\hline & Total & -.616 & .198 & 9.679 & 1 & .002 & .540 \\
\hline \multirow[t]{3}{*}{ Control of Emotions } & Men & -.936 & .290 & 10.420 & 1 & .001 & .392 \\
\hline & Women & -.531 & .313 & 2.883 & 1 & .090 & .588 \\
\hline & Total & .344 & .172 & 3.978 & 1 & .046 & 1.410 \\
\hline \multirow[t]{3}{*}{ Scrupulosity } & Men & .551 & 259 & 4.503 & 1 & .034 & 1.734 \\
\hline & Women & .298 & .267 & 1.244 & 1 & .265 & 1.348 \\
\hline & Total & -.276 & .200 & 1.899 & 1 & .168 & .759 \\
\hline \multirow[t]{2}{*}{ Perseverance } & Men & -.288 & .277 & 1.083 & 1 & .298 & .750 \\
\hline & Women & -.337 & .309 & 1.183 & 1 & .277 & .714 \\
\hline
\end{tabular}




\section{Orrit, G.; Pablos, A.; Guzmán, F.J.}

Adonis Complex $=-2.92-(.01 \times$ Integrity $)+(.02 \mathrm{x}$ Honesty $)+(.06 \times$ Responsibility $)+(.03 \times$ Social Commitment $)+(.00 \times$ Prosociability $)-(.10 \times$ Justice and Equality $)+(.04 \times$ Hedonism $)-(.09 \times$ Social Recognition $)-(.03 \times$ Harmonious Passion $)+(.08 \times$ Obsessive Passion $)+(.48 \times$ Dynamism $)-(.50 \times$ Domination $)$ - $(.27 \mathrm{x}$ Impulse Control $)-(.53 \mathrm{x}$ Emotional Control $)+(.29 \times$ Scrupulosity $)-(.33 \mathrm{x}$ Perseverance).

Highlight the importance of obsessive passion value $(\beta=085, \mathrm{p}=.024)$ as a risk factor. In this case, the Hosmer and Lemeshow test indicated an adequate deviation adjustment $(\mathrm{X} 2=7,16(8) \mathrm{p}=.052)$.

\section{DISCUSSION}

The aim of this study was to analyze which variables of personality, gender identity and passion (harmonious or obsessive) allow to predict MD in adolescents, measured from the perception of Adonis Complex. The results confirmed harmonious passion and emotional control as protective factors, and obsessive passion and scrupulosity as risk factors. There was also a tendency for justice and equality to be protective factors and for social commitment to be risk factor.

According to the results (men and women), in general, harmonious passion and emotional control are protective factors, so that adolescents who practice sports in a harmonious way and have emotional control have less risk to develop MD. While those who practice sports obsessively and tend to be scrupulous have more risk of developing MD. As for men in particular, they also add social commitment as a risk factor, which increases the risk of developing MD; while in women the Obsessive Passion stands out as a risk factor, but the model did not reach the significance level.

The results obtained with the variable passion are congruent with the results of previous studies that show that harmonious passion has been linked to positive aspects, generating in people motivation and autonomy, and stating that they enjoy sports practice; (Nogueira, Salguero del Valle, \& Márquez, 2017) while obsessive passion can be found related to psychophysiological disorders or symptomatology in subjects who do not enjoy sport practice and can even suffer from disorders such as the burn out syndrome (Aziz, Uhrich, Wuensch, \& Swords, 2013; Philippe,
Vallerand, Houlfort, Lavigne, and Donahue, 2010). Comparing the variable obsessive passion with the definition of the DSM-TR-V (APA, 2013) on MD, the relation that exists between this and the obsessive-compulsive spectrum MD can be observed.

Regarding the value of emotional control as a personality factor, it is verified how emotional control is a protective factor of MD (Martín de Benito, Guzmán, \& de Benito Trigueros, 2018) and the results obtained are in line with the concept of emotional control as the ability of people to modify their behavior in function of the demands of specific situations (Peñafiel \& Serrano, 2010). Subjects with low levels of emotional intelligence have greater impulsivity and worse interpersonal and social skills, which favors the appearance of antisocial behaviors. In addition, they are more involved in self-destructive behavior (Fernandez-Berrocal \& Ruiz, 2008). Subjects with high levels of emotional intelligence have a lower tendency to carry out impulsive actions (Jiménez \& López, 2013).

With regard to scrupulosity as a risk factor, and considering that scrupulous people may present obsessions or compulsions that consume time and energy, the results obtained are consistent with data from other studies that show that subjects with exercise addiction often have compulsive thoughts about the practice of exercise, which can lead to experience physical and psychological symptoms (Gutierrez \& Ferrerira, 2007).

On the other hand, although it did not reach significance, the value of social commitment as a risk factor may be associated with the ideal of the hypermuscle body of beauty and live in a body-cult society (Baile, 2005; Grieve, 2007). In the last decades being physically perfect has become one of the main objectives of the developed society.

The limitations of this research lie in the collection of the sample and in the availability of the participants for the data collection, which is reflected in the low participation of gym users in the sample, given the difficulties put by the managers of the gyms to allow the participants to access the facilities, so this may explain that there were no higher scores in the Adonis Complex. Related to the exposed limitation, although the sample was significant, it would be necessary to replicate the study with a larger sample. Tried to 


\section{Orrit, G.; Pablos, A.; Guzmán, F.J.}

increase the participation of users of fitness rooms of gyms.

\section{CONCLUSION}

In consideration of the results obtained and in accordance with the objectives of the study, it can be concluded that harmonious passion and emotional control are protective variables of MD because they predict the Adonis Complex variable significantly and negatively, while the obsessive passion and the scrupulosity are risk factors, because they were positively related to it. These results indicate the importance of developing intervention programs aimed at the prevention of MD; Highlighting the relevance of working on emotional control and harmonious passion with adolescents, considering that the adolescence stage is crucial for the development of MD, given the prevalence of the disorder.

The presented data contribute to reinforce the need to promote the practice of sports activity by teachers and sports coaches, promoting work on the emotional control of adolescents with a positive inclination (Harmonious Passion), given the consequences and the repercussion that has about them, since the study indicates that both emotional control and passion are related to the development of MD.

\section{PRACTICAL APPLICATION}

The data presented contribute on the one hand to reinforce the need to promote the practice of sports activity by teachers and sports coaches, working on the emotional control of adolescents with a positive inclination (harmonious passion), given the consequences and repercussion they have about them when it comes to physical activity. Preparing the ground for the individual to acquire the necessary coping skills to establish themselves in adulthood.

On the other hand, this study provides data that broaden knowledge about the predictive and protective factors of Muscular Dysmorphia or vigorexia, considering the importance of investigating in order to prevent this type of disorder, and be able to design specific programs of intervention based on the characteristics of the DM, aimed not only at athletes, coaches and directors of sports clubs, but also teachers and educators.

\section{REFERENCES}

1. American Psychiatric Associatión. (2013). Diagnostic and statistical manual of mental disorders (5 ed.). Washington, DC: Author. doi:https://doi.org/10.1176/appi.books.97808904 25596

2. Antolín, L., Oliva, A., Pertegal, M., \& López, A. (2011). Desarrollo y validación de una escala de valores para el desarrollo positivo adolescente. [Development and validation of a scale of values for adolescent positive development]. Psicothema, 23(1), 153-159. Retrieved from http://hdl.handle.net/11441/23218

3. Aziz, S., Uhrich, B., Wuensch, K., \& Swords, B. (2013). The Workaholism Analysis Questionnaire: Emphasizing Work-Life Imbalance and Addiction in the Measurement of Workaholism. Journal of Behavioral \& Applied Management, 14, 71-86.

4. Baile, J. (2005). Vigorexia. Cómo reconocerla y evitarla [Vigorexia How to recognize it and avoid it]. Madrid: Sintesis.

5. Castro-López, R., Molero, D., Cachón-Zagalaz, J., \& Sagalaz-Sánchez, M. L. (2014). Factores de Personalidad y Fisioculturismo: indicadores asociados a la vigorexia. Revista de Psicológia del Deporte, 23(2), 295-300.

6. Bermudez, J. (1995). Manual del Cuestionario "Big Five" (BFQ). [Manual of the "Big Five" Questionnaire (BFQ)]. Madrid: TEA.

7. Bjornsson, A., Didie, E., Grant, J., Menard, W., Stalker, E., \& Phillips, K. (2013). Age at onset and clinical correlates in body dysmorphic disorder. Compr Psychiatry, 54, 893-903. doi:http://dx.doi.org/10.1016/j.comppsych.2013. 03.019

8. Fernandez-Berrocal, P., \& Ruiz, D. (2008). La inteligencia Emocional en Educación. [Emotional Intelligence in Education]. Electronic Journal of Research in Educational Psychology 6(2), 0-0, 6(15), 421-436.

9. Galli, N., Petrie, T., Reel, J., Greenlealf, C., \& Carter, J. (2015, junio). Psychosocial predictors of drive for muscularity in male collegiate athletes. Body Image, 14, 62-65. doi:http://dx.doi.org/10.1016/j.bodyim.2015.03.0 09.

10. González-Martí, I., Fernández Bustos, J. G., \& Contreras Jordan, O. R. (2012). Contribución para el criterio diagnóstico de la Dismorfia Muscular (Vigorexia). Revista de Psicología del Deprte, 21(2), 351-358. 


\section{Orrit, G.; Pablos, A.; Guzmán, F.J.}

11. Greenberg, D., Witztum, E., \& Pisante, J. (1987). Scrupulosity: religious attitudes and clinical presentations. The Britis journal of medical psychology, 60(pt1), 29-37. doi:http://dx.doi.org/10.1111/j.20448341.1987.tb02714.x

12. Grieve, F. G. (2007). A Conceptual model of factors contributing to the development of Muscle Dysmorphia. Eeting Disorders, 15,63-80. doi:http://dx.doi.org/10.1080/1064026060104453 5

13. Gutierrez, C., \& Ferrerira, R. (2007). Estudio sobre la Adicción al Ejercicio: Un Enfoque de la Problemática actual. [Study on Exercise Addiction: An Approach to Current Issues]. Medellin: Universidad de antioquia.

14. Jiménez, M., \& López, E. (2013). Impacto de la inteligencia emocional percibida, actitudes sociales y expectativas del profesor en el rendimiento académico. [Impact of perceived emotional intelligence, social attitudes and teacher expectations on academic performance]. Electronic Journal of Research in Educational Psychology, 11(29), 75-98.

15. Martín de Benito, M., Guzmán Luján, F. J., \& de Benito Trigueros, A. M. (2018). Inteligencia emocional, percepción de apoyo a la autonomía y relaciones en el deporte. Cuadernos de Psicología del Deporte, 18(1), 13-20.

16. Melosik, Z. (2010). Tożsamość, ciało i władza w kulturze instant. [Identity, body and power in instant culture]. Croacia: Impuls.

17. Mitchell, L., Murray, S. B., Hoon, M., Hackett, D., \& Prvan, T. (2017). Correlates of muscle dysmorphia symptomatology in natural bodybuilders: Distinguishing factors in the pursuit of hyper-muscularity. Body Image, 22, 15. doi:http://dx.doi.org/10.1037/a0018017.

18. Nogueira López, A., Salguero del Valle, A., \& Márquez Rosa, S. (2017). Adicción a correr: una revisión desde sus inicios hasta la actualidad. Revista de Psicología Aplicada al Deporte y al Ejercicio Físico, 2(1), 11-22.

19. Orgambídez, A., Borrego, Y., \& Gonçalves, G. (2014). Passionate workers: Spanish adaptation of the Passion Scale. [Los trabajadores apasionados: Adaptación española de la Escala de Pasión]. Journal of Work and Organizational Psychology, 30(2), 43-48.
20. Peñafiel, E., \& Serrano, C. (2010). Habilidades sociales. [Social skills]. Madrid, España: Editex, S.A.

21. Philippe, F., Vallerand, R., Houlfort, N., Lavigne, G., \& Donahue, E. (2010). Passion for an activity and quality of interpersonal relationships: the mediating role of emotions. Journal of personality and social psychology, 98(6), 917-932. doi:http://dx.doi.org/10.1037/a0018017

22. Pope, H. G., Gruber, A. J., Mangweth, B., Bureau, B., De Col, C., Jouvent, R., \& Hudson, J. J. (2000). Body image Perception Among Men in three Countries. American Journal of Psychiatry(157), 1297-1301. doi:http://dx.doi.org/10.1176/appi.ajp.157.8.1297

23. Pope, H. G., Katz, D., \& Hudson, J. (1993). Anorexia Nervosa and " Reverse Anorexia" Among 108 Male Bodybuilders. Comprehensive Psychiatry(9), 406-409. doi:http://dx.doi.org/10.1016/0010440X(93)90066-D

24. Starzomska, M., \& Cylwik , M. (2013). W poszukiwaniu przyczyn bigoreksji: Wizerunek ciała a dobrostan u mężczyzn uczęszczających do siłowni w świetle wyników badań. [In search of the causes of bigorexia: Body image and wellbeing in men attending the gym in the light of research results]. Kwartalnik Naukowy FIDES ET RATIO, 1(13), 204-2017.

25. Urlych, I. (2013). Wielka bigoreksja-W wielkiej sieci [The great bigorexia-on the World Wide Web]. Wychowanie Fizyczne i Zdrowotne, 1, 2025.

26. Vallerand, R., \& Verner-Filion, J. (2013). Making people's life most worth living: On the importance of passion for positive psychology. Terapia psicológica, 25-48. doi:http://dx.doi.org/10.4067/S071848082013000100004

27. Walker, D. C., Anderson, D. A., \& Hildebrandt, T. (2009, junio). Body checking behaviors in men. Body Image, 6(3), 164-170.

28. Wilhelm , S., \& Steketee , G. (2006). Cognitive therapy for obsessive-compulsive disorder: A guide for professionals. Oakland, CA: New Harbinger Publications 